\title{
Fundamentalis dan Radikalis Islam di Tengah Kehidupan Sosial Indonesia
}

\author{
Muslim Mufti \\ (FISIP UIN Sunan Gunung Djati, Bandung, Indonesia; muslimmufti@uinsgd.ac.id) \\ M. Taufiq Rahman \\ (FISIP UIN Sunan Gunung Djati, Bandung, Indonesia; fikrakoe@uinsgd.ac.id)
}

\begin{abstract}
This article discusses the origins of fundamentalism and radicalism in Indonesia. This discussion is a new challenge for social studies in Indonesia considering that this country has a population with a majority of Muslims. By taking texts from contemporary books and journals, this study describes what is the formation of fundamentalism and radicalism, why it arises, and how it develops in Indonesia. This study found that various motives and opportunities emerged in Indonesia as a cause of the emergence of fundamentalism and radicalism. Finally, this study also suggests how well the Indonesian people face the threat of fundamentalism and radicalism.
\end{abstract}

Keywords: Islamic fundamentalism; religious radicalism; Indonesian society.

\begin{abstract}
Abstrak
Artikel ini membahas tentang asal-usul fundamentalisme dan radikalisme di Indonesia. Diskusi ini merupakan tantangan baru bagi kajian kemasyarakatan di Indonesia mengingat negeri ini mempunyai penduduk dengan mayoritas beragama Islam. Dengan mengambil teks-teks dari buku-buku dan jurnal kontemporer, kajian ini mendeskripsikan apa yang menjadi formasi dari fundamentalisme dan radikalisme, mengapa ia muncul, dan bagaimana perkembangannya di Indonesia. Kajian ini menemukan bahwa berbagai motif dan kesempatan muncul di Indonesia sebagai sebab dari kemunculan fundamentalisme dan radikalisme. Akhirnya, kajian ini pun menyarankan bagaimana baiknya bangsa Indonesia menghadapi ancaman fundamentalisme dan radikalisme tersebut.
\end{abstract}

Kata Kunci: fundamentalisme Islam; radikalisme agama; masyarakat Indonesia.

\section{A. Pendahuluan}

Terlepas dari berbagai motif dan tendensi-tendensi di balik semakin meningkatnya perhatian terhadap studi Islam dan masyarakat Islam, terutama yang 


\section{ARTIKEL \\ E-ISSN: $2615-5028$}

berfokus kepada gerakan Islam fundamentalis dan radikal, maka perhatian yang semakin intens juga mulai terlihat di kalangan sarjana dalam negeri sendiri. ${ }^{1}$ Apalagi dalam realitasnya Indonesia telah dituding oleh berbagai pihak sebagai salah satu sarang bagi operasi kaum teroris yang harus diwaspadai. Insiden Bom Legian Bali 12 Oktober 2002 yang kemudian diiringi dengan penangkapan dan peringkusan puluhan orang yang kemudian didakwa terlibat tindak terorisme, semakin menegaskan indikasi ke arah tersebut. ${ }^{2}$

Di berbagai negara yang lebih demokratis, sangat makmur, modern dan maju; terorisme dari kelompok fundamentalis ini, baik itu fundamentalisme agama ataupun politik ideologis, telah berkali-kali menimbulkan insiden yang serius. Di Amerika Serikat sendiri, beberapa peristiwa serupa sering terjadi, salah satu insiden yang kemudian menjadi populer adalah peristiwa yang melibatkan sekte keagamaan “Branch Davidian” (Cabang Daud) pimpinan David Koresh tahun 1993. Sebelumnya pada tahun 1978 di Guyana lebih 900 orang “people’s Temple” pimpinan Jim Jones di Guyana melakukan bunuh diri masal dengan menenggak racun. Terjadinya insiden yang melibatkan orang-orang yang tergabung dalam sekte yang menanamkan dirinya "Aum Shinri Kyo" (kebenaran tertinggi), yang dipimpin oleh seorang guru spritualnya Shoko Asahara dengan teror-teror serangan gas saraf yang mengerikan.

\footnotetext{
${ }^{1}$ Berbagai perbincangan, diskusi dan seminar yang membahas tentang fenomena fundamemtalisme keagamaan telah berkali-kali diselenggarakan, salah satunyua adalah dialog bersama antara tokoh-tokoh agama dengan beberapa diplomat asing di Indonesia beberapa bula lalu di Jakarta. Sebuah seminar internasional mengenai Islam dan terorisme pasca kejadian 11 September 2001 diselenggarakan pula di Jakarta pada akhir bulan agustus 2002.

${ }^{2}$ Ledakan Bom Bali yang menewaskan sekitar 200 orang, yang kebanyakan warga negara asing terutama Australia, dipandang sebagai titik kulminasi dari kejadian-kejadian peledakan bom misterius yang umumnya terjadi di berbagai gereja sepanjang tahun 1990-2002. Pada pertengahan 2003, ditengah hiruk pikuk persidangan para tersangka aksi terorisme, kembali terjadi aksi bom bunuh diri di Hotel Merriot Jakarta yang menewaskan dan melukai beberapa orang.
} 


\section{ARTIKEL}

E-ISSN: $2615-5028$

Fenomena ini bagaimanapun cukup memberikan gambaran bagaimana bahaya kelompok keagamaan yag ekstrem dapat saja hadir dimanapun dan kapanpun. ${ }^{3}$

Telah menjadi hampir rutinitas pula bahwa di negara-negara mayoritas muslim, seperti Mesir, Syria, Yordania, sering meletup ketegangan-ketegangan serius antara pemerintah dengan beberapa gerakan keagamaan ekstrem. Yang tidak jarang berakhir dengan konfrontasi berdarah. Sekiranya tidak terlalu salah untuk menyatakan bahwa sejarah panjang kegoncangan politik dan instabilitas yang berlangsung di kawasan ini kerapkali disebabkan oleh terjadinya pergesekan antara pemerintahan yang berkuasa dengan kelompok-kelompok fundamentalis. Dalam pemerintahan di negara-negara Arab yang didominasi oleh rezim militer ataupun kelompok klan kekeluargaan tersebut, aksi-aksi kelompok Islam militan ini telah hampir-hampir menjadi "hantu" yang bersifat mengancam dan menakutkan. ${ }^{4}$

Dalam sejarahnya, gerakan Islam fundamentalis di Indonesia dibandingkan dengan gerakan serupa lainnya di beberapa negara Timur Tengah ataupun Pakistan misalnya, tidak atau belum memperlihatkan pengaruh dan kekuatan yang cukup luas secara nasional. Sehingga kontestasi dengan kelompok-kelompok lain di luarnya tidaklah begitu diperhitungkan. Apalagi pemerintahan Orde Baru menerapkan kebijakan spesifik yang represif terhadap elemen-elemen semacam ini. Selain itu, mesti dipahami bahwa dalam dunia gerakan, Islam fundamentalis terdapat berbagai arus yang berbeda satu sama lain di antara mereka, baik dalam doktrin, pemikiran, metode, dan tujuan gerakannya. Bahkan tidak menutup kemungkinan akan terjadinya

${ }^{3}$ Lihat: Budhy Munawar Rachman, "Ekspresi Keberagaman: Kultus dan Fundamentalisme", dalam, Islam pluralis, (Jakarta, paramadina, 2001).

${ }_{4}^{4}$ Rahman, M. Taufiq. "Islam dan Demokrasi dalam Wacana Kontemporer." Risalah 51, no. 11 (2014): $72-75$. 


\section{ARTIKEL}

perselisihan diantara kelompok Islam fundamentalis akibat fragmentasi pemikiran dan ideologi ini.

Fundamentalisme Islam saat ini kiranya menjadi isu paling banyak menarik perhatian kalangan luas, baik di dalam negeri maupun di luar negeri. Selama beberapa waktu setelah terjadinya peristiwa 11 September 2001, yakni insiden robohnya bangunan besar yang selama ini disimbolkan sebagai lambang keadikuasaan Amerika Serikat sebagai kekuatan utama dunia : gedung World Trade Center (WTC) dan Gedung Pentagon, pernyataan-pernyataan yang terkait dengan fundamentalisme Islam selalu mendapat publisitas yang sangat luas di seluruh dunia, tak terkecuali di dunia Islam sendiri.

Tidak perlu menunggu terlalu lama, pemerintahan di berbagai negara muslim mulai dengan gencar melontarkan manifesto-manifesto secara seragam yang bernada kutukan dan hujatan terhadap segala yang berbau fundamentalisme dan radikalisme agama. Dengan begitu, fundamentalisme Islam, dengan segera saja menjadi idiom paling populer dan sekaligus terkontruksi sebagi musuh (enemy) kehidupan umat manusia yang sudah seharusnya dienyahkan keberadaannya. Apalagi kebanyakan kelompok-kelompok yang dikaitkan dengan fundamentalisme ini umumnya merupakan bagian dari penentang pemerintah yang berkuasa. Sebagaimana berbagai pencitraan yang tidak selalu tepat, pemakaian istilah fundamentalisme untuk mendiskripsikan atau identifikasi terhadap gerakan-gerakan Islam yang menganut arus tertentu, juga tidak luput dari berbagai problematika serius. Salah satu persoalannya ialah bahwa terma fundamentalisme lahir dalam suatu konteks kebudayaan dan agama yang spesifik, yakni pengalaman Kristen.

\section{B. Metode}




\section{ARTIKEL}

E-ISSN: $2615-5028$

Studi ini menggunakan pendekatan kualitatif. Penggunaan metode kualitatif ini didasarkan atas tiga pertimbangan. Pertama, lebih mudah menyesuaikan dengan kenyataan faktual. Kedua, kemampuannya dalam menyajikan hakikat hubungan antara peneliti dengan informan/responden. Ketiga, lebih peka dan adaptif terhadap polapola nilai. ${ }^{5}$ Penelitian kualitatif menurut Bodgan dan Taylor adalah prosedur penelitian yang menghasilkan data deskriptif berupa kata-kata tertulis atau lisan dari orang-orang dan pelaku yang dapat diamati. ${ }^{6}$ Dalam pendekatan kualitatif ini fokus perhatiannya adalah pada realitas sosial yang selalu berubah dan merupakan hasil konstruksi sosial yang berlangsung antara pelaku dan institusi sosial. ${ }^{7}$

Berdasarkan tujuannya, penelitian ini termasuk dalam kategori penelitian deskriptif, yaitu penelitian yang berusaha menggambarkan rincian-rincian spesifik dari situasi, setting atau relasi-relasi sosial yang berlangsung dalam lingkup subyek penelitian. ${ }^{8}$ Oleh karena itu, tipe penelitian ini bersifat deskriptif analitis. Tipe penelitian ini adalah suatu tipe penelitian yang berusaha menggambarkan realitas sosial yang kompleks melalui penyederhanaan dan klarifikasi dengan memanfaatkan konsep-konsep yang bisa menjelaskan suatu gejala sosial secara analitis. ${ }^{9}$

\section{Hasil dan Pembahasan}

Istilah fundamentalisme dalam pandangan Martin van Bruinessen, mengimplikasikan suatu peneguhan kembali atas kebenaran kepercayaan sebagaimana

\footnotetext{
${ }^{5}$ Robinson, David, and Val Reed. The A-Z of social research jargon. Routledge, 2019.

${ }^{6}$ Ibid.

${ }^{7}$ Blaikie, Norman, and Jan Priest. Designing social research: The logic of anticipation. John Wiley \& Sons, 2019.

${ }^{8}$ Van Dijk, Teun A. Macrostructures: An interdisciplinary study of global structures in discourse, interaction, and cognition. Routledge, 2019.

9 Ponsioen, Johannes Antonius. The analysis of social change reconsidered: A sociological study. Vol. 4. Walter de Gruyter GmbH \& Co KG, 2019.
} 
ada dalam kitab suci Bibel, yang kembali ditegakkan dalam rangka menghadapi serangan gencar ilmu pengetahuan sekuler, terutama dalam menghadapi teori evolusinya Darwin. ${ }^{10}$ Namun, ketika terma yang bermakna spesifik ini dicoba untuk ditransfer kepada fenomena historis, kultural dan keagamaan yang berlainan dengan konteks dimana istilah ini dilahirkan, ternyata menimbulkan beberapa kesulitan tertentu.

Yang pertama, secara doktrinal, Islam memiliki perbedaan-perbedaan yang mendasar apabila dibandingkan dengan ajaran dan tradisi Kristiani. Yang kedua, terma fundamentalisme yang mulai diletakkan kepada kecenderungan tertentu dalam kepercayaan dan agama-agama lain non Kristiani, terutama Islam, adalah merupakan fenomena yang dimulai sekitar 1970-an yang berkembang di kalangan para ilmuwan saat melihat berlangsungnya revivalisme keagamaan di berbagai belahan dunia.

Dalam masyarakat keagamaan apapun dan dimanapun, komunitas masyarakat dengan pola kehidupan ortodoksi dan puritanisme kiranya merupakan entitas yang selalu hadir meskipun dalam tekanan dan skala ortodoksi yang tidak persis sama. Kenyataan itu telah merupakan bagian dari sejarah keagamaan itu sendiri. ${ }^{11}$ Namun demikian, konteks kehadiran revivalisme agama dan kepercayaan-kepercayaan yang sama sebagaimana sering dikaitkan dengan kecenderungan tertentu dalam gerakan kelompok-kelompok religius baik itu dari kalangan umat Islam, Yahudi, Buddha, Hindu, Sikh, dan lain sebagainya, telah dilihat dalam perspektif dan nuansa yang berbeda. Revivalisme masa kini itu sendiri merupakan respons atas keadaan-keadaan

10 Martin van Brunessen, "Muslim Fundamentalism: Something to be Understood or to be Explained Away?", dalam Howard M. Federspiel (general editor), An Anthology of Islamic studies, (Institute of Islamic Studies Mc Gill University, 1996), Vol. II, hal. 88.

11 Rahman, M. Taufiq. "A. Revivalist álims' response to development: A. Latief Muchtar of the Persatuan Islam in Indonesia’s New Order." JISPO: Jurnal Ilmu Sosial dan Ilmu Politik 2, no. 2 (2014): 112. 


\section{ARTIKEL}

E-ISSN: $2615-5028$

yang sangat berbeda dengan saat ketika fundamentalis Kristen muncul di Amerika dan beberapa negara Eropa abad ke-19. Karakteristik dan persoalan yang melingkupi fundamentalisme modern jauh bersifat lebih kompleks.

Wiliam E. Shepard ${ }^{12}$ mencatat karakteristik-karakteristik umum yang melekat dalam diri kelompok Islam radikal atau Islam fundamentalis ini, antara lain: Pertama, mereka mengklaim bahwa Islam merupakan suatu totalitas dari segala aspek kehidupan sosial dan personal. Dalam dimensi-dimensi tertentu mereka sepaham dengan kelompok modernis tentang fleksibilitas Islam, perlunya melakukan ijtihad meskipun dibatasi hanya dalam ruang lingkup yang minimal. Kaum Islam fundamentalis sangat menekankan dijalankannya ajaran Islam yang bersifat autentik dan tidak secara terselubung atau pura-pura menjiplak Barat.

Kedua, mereka sangat menekankan kekhususan Islam. Kecenderungan kepada pengkhususan Islam dapat mewujudkan diri dalam sebuah desakan atas kekhususan hukum-hukum Islam yang bersifat jelas, seperti hukuman hudud. Meskipun demikian, secara lebih subtil kekhususan itu didorong oleh penekanan bahwa Islam sebagai suatu totalitas adalah suatu sistem yang khusus dan terintegrasi, sekalipun bagian-bagian individual tidak terlihat khusus, tempat mereka dalam sistem Islam menjadikan mereka berbeda. Sealur dengan pendekatan ini, sering dinyatakan bahwa hukuman seperti memotong tangan seorang pencuri sudah semestinya diterapkan, hanya jika setelah masyarakat Islam yang sebenarnya terwujud. ${ }^{13}$

Ketiga, kaum fundamentalis cenderung tidak mau berkompromi terhadap persoalan-persoalan minoritas nonmuslim. Maududi misalnya secara terang-terangan

12 Wiliam E. Shepard, "Islam and Ideology: Toward A Typhology", dalam International of Journal Midlle East Studies, Vol. 19 (1987), hal. 301-305.

${ }^{13}$ Khan, Bill. Democracy and Islam: Two Systems of Governance. iUniverse, 2019. 


\section{ARTIKEL}

E-ISSN: $2615-5028$

menentang prinsip "equality before the law" sebagai suatu kepura-puraan dan mempertahankan ketentuan pemberian status dhimmi buat mereka. ${ }^{14}$

Keempat, lebih dari pada yang lain, kaum fundamentalis atau radikal Islam menekan atau mendorong sangat perlunya penerapan syari'at dalam praktek kehidupan. Syariah tidak hanya suatu ideal yang dikenalkan dan di-ta'zhimi (revered) tetapi suatu hukum yang dibuat untuk diberlakukan dan ditaati. ${ }^{15}$

Kelima, kendatipun, kaum fundamentalis menekankan kesadaran kepada autentisitas atau keaslian, mereka sebenarnya modern dan menerima banyak hal yang baru yang merupakan pinjaman dari Barat. Dengan sangat jelas, tidak terdapat persoalan bagi mereka untuk menerima bahan atau alat hasil teknologi modern, sebagaimana peranan kaset tape rekorder dalam Revolusi Iran dan pemakaian senjata-senjata modern dalam perang Iran-Irak. Lebih dari itu semua, kaum radikal Islam juga dapat menerima. Dan memanfaatkan secara efektif berbagai metode politik dan organisasi sosial yang bersumber dari Barat dan untuk menyesuaikan setidaknya simbol-simbol dan ide-ide politik Barat. Ini telah ditunjukkan misalnya dalam Republik Islam Iran yang memiliki partai, parlemen, pemilu, dan sebagainya. ${ }^{16}$ Termasuk berbagai hal yang diperhatikan Maududi di Pakistan.

Keenam, kaum fundamentalis pada kenyataannya menerima gagasan (ide) tentang kemajuan. ${ }^{17}$ Tuduhan bahwa mereka, karena semangatnya mengikuti Sunnah Nabi, dianggap ingin "kembali ke masa lampau" merupakan salah pengertian yang

\footnotetext{
${ }^{14}$ De Bellaigue, Christopher. The Islamic Enlightenment: The Struggle Between Faith and Reason, 1798 to Modern Times. Liveright Publishing, 2017.

${ }^{15}$ Kuran, Timur. "The rule of law in Islamic thought and practice: A historical perspective." In Global perspectives on the rule of law, pp. 87-106. Routledge-Cavendish, 2013.

${ }^{16}$ Owen, Roger. State, power and politics in the making of the modern Middle East. Routledge, 2013.

${ }^{17}$ Haynes, Jeffrey. "Peace, Politics, and Religion." In The Palgrave Handbook of Global Approaches to Peace, pp. 643-662. Palgrave Macmillan, Cham, 2019.
} 


\section{ARTIKEL}

E-ISSN: $2615-5028$

serius. Sebaliknya, mereka tidak hanya menginginkan kemajuan tetapi juga menyatakan bahwa Islam merupakan jalan untuk mencapainya. Meskipun tidak diragukan bahwa kaum fundamentalis ini ingin melenyapkan dampak-dampak dari model kemajuan Barat, tetapi bukan berarti mereka memutar jarum jam ke belakang.

Meskipun sudah menjadi kecenderungan umum atau arus besar pengkaji politik Islam meletakkan istilah fundamentalisme Islam sebagai sebuah kategorisasi, yang secara diametral sering didudukkan secara berlawanan dengan arus-arus Islam lainnya, semacam Islam yang moderat ataupun Islam yang modernis, tetapi tidak sedikit di kalangan peneliti gerakan Islam yang merasa keberatan dengan pemakaian istilah fundamentalisme ini.

John L. Esposito, misalnya, melihat fundamentalisme tidaklah merupakan istilah yang netral, tetapi di dalamnya termaktub berbagai tendensi dan stereotype yang tidak bersesuaian dengan Islam. ${ }^{18}$ Selain istilah fundamentalisme dibebani dengan praduga Kristen dan Barat, Esposito juga menyebutkan pemakaian istilah itu menyiratkan adanya ancaman monolitik yang sebenarnya tidak bersifat nyata. Kemudian, ia menawarkan istilah yang menurutnya lebih tepat, yakni: "kebangkitan Islam" atau "aktivisme Islam", yang lebih memiliki akar dalam tradisi kesejarahan Islam.

Dengan alasan yang hampir sama, seorang juru bicara "fundamentalis moderat" paling berpengaruh saat, Yusuf Qardhawy, merasa keberatan dengan istilah fundamentalisme (al-ushuliyah) bagi gerakan Islam. Yang lebih tepat, menurutnya adalah istilah kebangkitan atau kesadaran (al-shahwah) untuk mengagambarkan

18 Esposito, John L. "Islamophobia and Radicalization: Roots, Impact and Implications." In Islamophobia and Radicalization, pp. 15-33. Palgrave Macmillan, Cham, 2019. 


\section{ARTIKEL}

fenomena Islam kontemporer. ${ }^{19}$ Nada keberatan yang serupa diperlihatkan juga oleh cendekiawan Muhammad Imarah. ${ }^{20}$

Dalam pandangan penulis, pemakaian kedua istilah tersebut baik itu fundamentalisme Islam atau Islam fundamentalis, maupun istilah Kebangkitn Islam (al-shahwah), masing-masing mengandung beberapa problem tertentu. Dan, keduanya, pada hemat penulis, memiliki pengertian atau makna yang tidaklah sama. Bahwa "fundamentalisme" merupakan sebuah suku kata yang bukan berasal atau ditarik dari kesejarahan Islam dan karenanya dianggap a-historis, melainkan produk fenomena historis dari peradaban dan agama samawi lain, bukan berarti secara serta merta akan menyesatkan untuk digunakan dalam menjelaskan realitas kontemporer dalam gerakan Islam. Setidaknya, sebagai suatu kategorisasi yang merujuk kepada keyakinan dan doktrin keberagaman yang spesifik, dan utuk membedakan dengan corak-corak yang lain.

Pemakaian ungkapan "kebangkitan" untuk merujuk kepada trend-trend gerakan Islam kontemporer bukannya akan menawarkan lebih sedikit persoalan. Justru sebaliknya, akan bersifat lebih banyak krusial. Apabila yang dimaksud sebagai "kebangkitan" saat ini dianggap merupakan sebuah kontinuitas dari era renaissance (zaman keemasan) peradaban Islam pada abad-abad pertengahan, maka justru akan memunculkan persoalan yang serius yang terkait dengan berbagai kontradiksikontradiksi tak terbantah antara kultur yang terkandung pada gerakan “kebangkitan”(al-shahwah) yang apabila itu dilekatkan kepada gerakan semacam takfir wal hijra, Ikhwanul Muslimin, jihad Islam, Jamaah Al-Islamiah, dan sebagainya.

\footnotetext{
19 Yusuf Qardhawy, Masa Depan Fundamentalisme Islam, (Jakarta, Pustaka Alkautsar, 1997), hal. 16. 20 Muhammad Imrah, Fundamentalisme dalam Perspektif Pemeikiran Barat dan Islam, (Jakarta, Gema Insani Press, 1999).
} 


\section{ARTIKEL}

E-ISSN: $2615-5028$

Kecenderungan umum kelompok-kelompok ini yang ke arah ortodoksi, dogmatisme, pandangan yang serba hitam-putih, sikap yang ekslusif, merasa paling benar, kiranya akan bersifat berlawanan secara diametral dengan sifat-sifat dan kultur umum Islam sengan periode kebangkitan yang sebenarnya atau periode keemasannya yang bersifat budaya metropolis, Islam yang pluralis, innovatif, penuh toleransi, terbuka terhadap sumber-sumber pengetahuan asing: termasuk pemikiran "non Islam” yang baik berasal Yunani dan Romawi ataupun yang lainnya, dan menghargai sikap yang rasional.

Bassam Tibi menjelaskan hadirnya fundamentalisme islam dalam kerangka atau spektrum yang bersifat lebih luas. Fundamentalisme diletakkan sebagai respon terhadap problem-problem yang berkaitan dengan globalisasi dan fragmentasi. Globalisasi yang merambah segala bidang: ekonomi, sosial, budaya, teknologi, komunikasi, dan sebagainya, telah mengimplikasikan terjadinya "penyempitan bumi", namun demikian ia ternyata tidak serta merta dibarengi dengan kemampuannya untuk menciptakan suatu kesatuan pandangan (bersifat kultural) dalam dirinya sendiri. Pada akhirnya dunia yang terglobalisasi serta merta merupakan dunia yang lebih terfragmentasi. Asumsi bahwa globalisasi dan fragmentasi bakal mengakibatkan suasana kacau balau dan serba tidak menentu inilah yang oleh kalangan fundamentalis dianggap sebagai semacam wabah atau ancaman. Selanjutnya mereka memilih bersikap menyempal dan melakukan "pemberontakan melawan Barat". ${ }^{21}$

Selain fundamentalisme agama dianggap sebagai kelompok penyempal (splinter group) dari arus globalisasi dan fragmentasi tersebut, Bassam Tibi menyatakan pula

21 Tibi, Bassam. "War and peace in Islam." In The Use of Force in International Law, pp. 47-64. Routledge, 2017. 


\section{ARTIKEL}

E-ISSN: $2615-5028$

bahwa fundamentalisme Islam pada dasarnya merupakan produk yang tumbuh dari terjadinya ketegangan-ketegangan antara pandangan dunia modernitas budaya dan pandangan dunia kosmologis monoteisme Islam. Ketegangan ini memiliki akar historis yang sangat panjang dalam kaitan perjumpaan antara peradaban islam dengan ekspansi peradaban Barat ke dunia Islam yang mengusung teknologi modern. ${ }^{22}$

Dalam sebuah riset sosiologis yang sangat luas dan menarik terhadap orangorang yang telibat dalam gerakan radikal Islam di Mesir (Takfir wal Hijra, Ikhwanul muslimin, Mujahidiin, dan Munazzamat al Tahrir al-Islami) pada akhir 1970-an, Saad Eddin Ibrahim, ${ }^{23}$ mencatat beberapa tipikal para anggota gerakan ini, yakni: kelompok ini tumbuh dari kalangan yang terutamanya berasal dari sektor-sektor menengah dan lebih rendah dari kelas menengah baru; mereka sebelumnya memiliki latar belakang (background) pedesaan, yang mengalami untuk pertama kali hidup dalam area metropolitan yang sangat luas dimana pengaruh asing sangat terlihat dan dalam mana daya impersonal dalam titik kekuatan yang maksimum. Terlihat juga, dalam beberapa hal, krisis nasional yang akut dakan besifat kait mengkait dengan kemunculan rasa kefrustasian sosial dan psikologis. Kombinasi dari berbagai faktor dalam sejarah Mesir: krisis nasional, rasa ketidakpuasan atau ketidaklayakan pada kelasnya (class incongruity), dan besarnya tingkat anomi individual, merupakan faktor yang mengkondisikan mereka untuk terjun dalam gerakana radikal Islam. ${ }^{24}$

\section{Kesimpulan}

\footnotetext{
22 Ibid., hlm 49.

${ }^{23}$ Ibrahim, Saad Eddin. Egypt Islam and democracy: Critical essays. American Univ in Cairo Press, 2002.

${ }^{24}$ Gerakan kiri atau Marxist tidak cukup populer bagi kalangan ini disebabkan, sebagaimana dicatat Saad Eddin Ibrahim, keberhasilan elit-elit penguasa yang menstigma sebagai ateis dan agen dari kekuatan asing (Uni Soviet), yang dituduh merusak dan menghancurkan Islam dan kebudayaan Mesir. Ibrahim, Saad Eddin. Egypt Islam and democracy: Critical essays. American Univ. in Cairo Press, 2002.
} 
Ada beberapa hal yang dapat dicatat dari menularnya sikap fundamentalis dan radikalis di kalangan anak muda Indonesia, yaitu: tidak adanya kredibilitas visi nasional sekuler dan kurangnya sarana-sarana efektif untuk membentengi gangguan dari luar, untuk meningkatkan prospek ekonomi saat ini. Sebaiknya ke depan kelompok masyarakat menengah dan atas untuk menggembleng impian dari kaum muda terdidik dan memberikan kepada meraka perasaan menjadi bagian yang penting dari grand design cita-cita nasional dan kemanusiaan.

\section{DAFTAR PUSTAKA}

Blaikie, Norman, and Jan Priest. Designing social research: The logic of anticipation. John Wiley \& Sons, 2019.

De Bellaigue, Christopher. The Islamic Enlightenment: The Struggle Between Faith and Reason, 1798 to Modern Times. Liveright Publishing, 2017.

Esposito, John L. "Islamophobia and Radicalization: Roots, Impact and Implications." In Islamophobia and Radicalization, pp. 15-33. Palgrave Macmillan, Cham, 2019.

Haynes, Jeffrey. "Peace, Politics, and Religion." In The Palgrave Handbook of Global Approaches to Peace, pp. 643-662. Palgrave Macmillan, Cham, 2019.

Ibrahim, Saad Eddin. Egypt Islam and democracy: Critical essays. American Univ in Cairo Press, 2002.

Imarah, Muhammad. Fundamentalisme dalam Perspektif Pemikiran Barat dan Islam, Jakarta, Gema Insani Press, 1999. 


\section{ARTIKEL}

Khan, Bill. Democracy and Islam: Two Systems of Governance. iUniverse, 2019.

Kuran, Timur. "The rule of law in Islamic thought and practice: A historical perspective." In Global perspectives on the rule of law, pp. 87-106. RoutledgeCavendish, 2013.

Ponsioen, Johannes Antonius. The analysis of social change reconsidered: A sociological study. Vol. 4. Walter de Gruyter GmbH \& Co KG, 2019.

Qardhawy, Yusuf. Masa Depan Fundamentalisme Islam, Jakarta, Pustaka Alkautsar, 1997.

Rachman, Budhy Munawar. "Ekspresi Keberagaman: Kultus dan Fundamentalisme", dalam Islam Pluralis, Jakarta, paramadina, 2001.

Rahman, M. Taufiq. "A. Revivalist álims' response to development: A. Latief Muchtar of the Persatuan Islam in Indonesia's New Order." JISPO: Jurnal Ilmu Sosial dan Ilmu Politik. 2, no. 2 (2014): 1-12.

Rahman, M. Taufiq. "Islam dan Demokrasi dalam Wacana Kontemporer." Risalah 51, no. 11 (2014): 72-75.

Robinson, David, and Val Reed. The A-Z of social research jargon. Routledge, 2019.

Shepard, Wiliam E. "Islam and Ideology: Toward A Typhology", dalam International of Journal Midlle East Studies, Vol. 19 (1987), hal. 307-305.

Tibi, Bassam. "War and peace in Islam." In The Use of Force in International Law, pp. 47-64. Routledge, 2017.

Van Brunessen, Martin. "Muslim Fundamentalism: Something to be Understood or to be Explained Away?", dalam Howard M. Federspiel (general editor), An 


\section{ARTIKEL}

\section{E-ISSN: 2615-5028}

Anthology of Islamic studies, Institut of Islamic Studies Mc Gill University, 1996, Vol. II.

Van Dijk, Teun A. Macrostructures: An interdisciplinary study of global structures in discourse, interaction, and cognition. Routledge, 2019. 